A N N A L E S

UNIVERSITATIS MARIAE CURIE-SKŁODOWSKA

LUBLIN - POLONIA

VOL. LXIII, 2

SECTIO G

2016

Uniwersytet Marii Curie-Skłodowskiej w Lublinie

antoni.hanusz@umcs.pl

paulina.krukowska@poczta.umcs.lublin.pl

ANTONI HANUSZ, PAULINA KRUKOWSKA-SIEMBIDA

\title{
Ważny interes podatnika i interes publiczny w klauzulach generalnych Ordynacji podatkowej
}

Taxpayer's Important Interest and Public Interest in General Clauses

of the Tax Ordinance Act

1.

Badając regulacje podatkowe pod kątem ich stabilności i elastyczności, należy zwrócić uwagę, że efekty stanowionego prawa są uzależnione od kilku czynników. Podstawowym jest wybór środków techniki prawodawczej zapewniających elastyczność przepisów prawnych, wśród których znajdują się także klauzule generalne ${ }^{1}$. W dalszej kolejności należy wskazać na właściwe umiejscowienie klauzul generalnych w danym akcie normatywnym. O ich skuteczności stanowi natomiast $\mathrm{w}$ dużym stopniu treść klauzul generalnych wyznaczająca mniejszy lub większy stopień swobody interpretacyjnej².

Przepisy Ordynacji podatkowej zawierają stosunkowo niewiele zwrotów i wyrażeń normatywnych, w których można odnaleźć klauzule generalne 3 .

1 Innym sposobem zapewnienia luzu decyzyjnego w procesie stosowania prawa jest operowanie przez normodawcę zwrotami nieokreślonymi i nieostrymi, czyli takimi, w których brak jest zdefiniowanego znaczenia wyrazu bądź wyraźnego zakresu mimo znajomości znaczenia.

2 Por. Z. Ziembiński, Teoria prawa, Warszawa - Poznań 1973, s. 131; P. Borszowski, Elastyczność a zwrot szacunkowy ,ważny interes podatnika" w konstrukcji umorzenia zaległości podatkowych, [w:] Instytucje prawnofinansowe w warunkach kryzysu gospodarczego, red. W. Miemiec, K. Sawicka, Warszawa 2014, s. 190.

3 Znacznie więcej w tekście Ordynacji podatkowej występuje pojęć nieokreślonych. Terminy o wyraźnie nieostrym zakresie znajdują się w: art. $67 \mathrm{~d} \S 1$ pkt 1 , gdzie mowa jest o uzasadnionym przypuszczeniu; art. 138 §e, w którym wskazuje się na podjęcie czynności niecierpiącej 
W większości ustawodawca posługuje się zbliżonymi do siebie pojęciowo klauzulami generalnymi, które odsyłają interpretatora do oceny ważnego interesu podatnika oraz interesu publicznego. Zwrot „ważny interes podatnika” został sformułowany w przepisach art. $22 \S 1$ i $\S 2$, art. $48 \S 1$ i $\S 2$, art. $67 \mathrm{a} \S 1$ oraz art. 253 i 253a Ordynacji podatkowej. W tych samych przepisach odsyła się również do oceny interesu publicznego. Oba różniące się w swej treści zwroty normatywne pozostawiają jednak organom podatkowym określenie we własnym zakresie pojęcia ważnego interesu podatnika oraz interesu publicznego.

Użyte w przepisach Ordynacji podatkowej takie pojęcia, jak „,ważny interes podatnika” oraz „interes publiczny” pod względem treści nie mają stałego zakresu. Organy podatkowe w czasie rozpatrywania poszczególnych spraw są zatem obowiązane według własnego rozeznania wypełnić te pojęcia właściwą zawartością. W ten sposób klauzule generalne powodują uelastycznienie tekstu aktu prawnego, a co za tym idzie - stosowania przepisów prawnych. Jednocześnie analiza przepisów art. $22 \S 1$ i $\S 2$, art. $48 \S 1$ i $\S 2$, art. $67 \mathrm{a} \S 1$ oraz art. 253 i 253a Ordynacji podatkowej prowadzi do przekonania, że klauzule generalne skłaniają $\mathrm{w}$ istocie organy podatkowe do dokonywania wyboru określonych w tych przepisach konsekwencji prawnych. Organy stosujące przepisy prawa podatkowego zawierające klauzule generalne mają więc swobodę w wyborze jednej z możliwych konsekwencji ${ }^{4}$. Minister Finansów może więc na podstawie art. $22 \S 1$ pkt 1 Ordynacji podatkowej zaniechać poboru podatku, wydając stosowne rozporządzenie, albo odmówić zaniechania poboru określonym grupom podatników. Z podobnym rezultatem postępowania można się spotkać, gdy właściwy organ podatkowy na podstawie art. $253 \S 4$ Ordynacji podatkowej wydaje decyzję w sprawie uchylenia lub zmiany dotychczasowej decyzji ostatecznej, jeżeli uzna, że zaistniał ważny interes podatnika, albo odmawia jej wydania na podstawie tego samego przepisu prawnego.

zwłoki; art. $155 \S 1$, dotyczącym podjęcia czynności niezbędnych do wyjaśnienia stanu faktycznego lub rozstrzygnięcia sprawy. Por. także: L. Leszczyński, Interpretacyjna rola kryteriów otwartych i innych decyzji stosowania prawa, [w:] System Prawa Administracyjnego, t. 4: Wykładnia w prawie administracyjnym, red. L. Leszczyński, B. Wojciechowski, M. Zirk-Sadowski, Warszawa 2015, s. 336 i n.

4 Dyrektywy wyboru konsekwencji wskazują tylko na to, jakie czynniki należy brać pod uwagę, natomiast czynniki te nie wpływają na jego wybór. Zob. więcej: idem, Stosowanie generalnych klauzul odsyłających, Kraków 2004, s. 21. 
Klauzule generalne zamieszczone w przepisach Ordynacji podatkowej odsyłają do dwóch ocen pozaprawnych: ważnego interesu podatnika oraz interesu publicznego. Wynika z tego, że kryteria oceny, którymi powinien się kierować organ podatkowy, zostały wyrażone pojęciami ogólnymi w sposób nieokreślony ${ }^{5}$. Takie formułowanie przepisów prawnych może zatem budzić poczucie braku bezpieczeństwa. Klauzule generalne odsyłające do ocen pozaprawnych mogą bowiem uzależniać podatników od dowolnego stosowania prawa przez organy podatkowe.

Pomimo tego w obliczu trudności oraz bezzasadności wyrażania w przepisach prawnych stałego i ścisłego kryterium oceny pewnych zjawisk, ustawodawca obciąża organ stosujący prawo obowiązkiem oceny danego stanu faktycznego. Pociąga to za sobą konkretyzację wyrażeń nieostrych. W jej ramach organ stosujący prawo dysponuje swobodą w obszarze wykładni zwrotów nieokreślonych i ogólnych pojęć prawnych oraz oceny stanów faktycznych odnoszących się do przepisów formułujących klauzule generalne. W ten sposób ustawodawca celowo pozostawia takiemu podmiotowi dość dużą swobodę interpretacyjną.

W praktyce stosowania prawa pojawia się jednak kwestia nie tylko ustalenia treści ogólnych i nieostrych pojęć prawnych, do których należą ważny interes podatnika i interes publiczny. Równie istotna staje się ocena konkretnych okoliczności faktycznych występujących w danej sprawie. Powinna ona być dokonana przez pryzmat pojęć użytych w klauzuli generalnej oraz określenie wzajemnej relacji między tymi pojęciami. Niezbędne zatem staje się ważenie przez organ podatkowy interesu publicznego i ważnego interesu podatnika. Analiza językowa wskazanych wyżej przepisów Ordynacji podatkowej prowadzi do przekonania, że należy tego dokonywać z uwzględnieniem stanowiska, że obie przesłanki powinny mieć charakter samodzielny i niezależny ${ }^{6}$. Ustawodawca

$5 \quad$ Szerzej na temat zwrotów nieokreślonych zob. idem, Tworzenie generalnych klauzul odsyłających, Lublin 2000, passim; A. Chodun, Klauzule generalne i zwroty niedookreślone - wybrane zagadnienia teoretyczne, [w:] A. Choduń, A. Gomułowicz, A. Skoczylas, Klauzule generalne $i$ zwroty niedookreślone $w$ prawie podatkowym $i$ administracyjnym. Wybrane zagadnienia teoretyczne i orzecznicze, Warszawa 2013, s. 16 i n.

6 Według T. Gizberta-Studnickiego katalog minimalnych wymagań, którym powinno odpowiadać rozstrzyganie konfliktów przez ważenie określonych dóbr, powinien obejmować takie zasady, jak: 1) właściwa identyfikacja dóbr będących w kolizji i ustalenie, czy rzeczywiście podlegają one ochronie prawnej, ich treściowe określenie i przypisanie właściwym podmiotom, 2) ustalenie abstrakcyjnej hierarchii dóbr, 3) podanie kryteriów oszacowania wagi poszczególnych dóbr w odniesieniu do konkretnego stanu faktycznego, przy czym kryteria te powinny mieć charakter 
podatkowy, wprowadzając zwrot szacunkowy artykułujący ważny interes podatnika jako pewną szczególną sytuację, nie uzupełnił bowiem tego wyrażenia klauzulą generalną odsyłającą do jednoczesnej oceny interesu publicznego ${ }^{7}$. W związku z tym ważny interes podatnika $i$ interes publiczny nie stają się wobec siebie konkurencyjne, ponieważ żaden z nich nie może być uznany z definicji za hierarchicznie ważniejszy ${ }^{8}$.

Klauzule generalne, jako środek techniki legislacyjnej, są wykorzystywane w celu zastosowania niezmiennego pod względem treści przepisu prawa podatkowego przy zachowaniu pewnego stopnia swobody na etapie jego wykładni. Doniosłą rolę w stosowaniu klauzul generalnych mają zobiektywizowane kryteria oceny przesłanki ważnego interesu podatnika oraz interesu publicznego. Skoro tak, to powinny być one zgodne z powszechnie aprobowaną $\mathrm{w}$ danym czasie społeczną hierarchią wartości. Wysoką rangę wśród takich wartości mają między innymi zdrowie i życie, godność ludzka oraz możliwości zarobkowe w celu zdobycia środków utrzymania dla siebie i rodziny ${ }^{9}$.

Przyjmując określony system wartości, ważny interes podatnika pojawia się jako sytuacja nadzwyczajna, przypadek losowy lub inne nadzwyczajne względy, które mogłyby zachwiać podstawami egzystencji podatnika ${ }^{10}$. Ważny interes podatnika należy jednak oceniać nie tylko w kontekście osobistej sytuacji majątkowej podatnika, lecz z uwzględnieniem związku zachodzącego między obniżeniem zdolności płatniczej a zaistnieniem wypadków powodujących i uzasadniających brak możności zapłaty podatku. W ten sposób kryteria oceny przesłanki ważnego interesu podatnika oraz interesu publicznego nabierają zobiektywizowanego charakteru.

generalny, tzn. nie powinny odwoływać się do indywidualnej właściwości stanu rzeczywistego. Por. T. Gizbert-Studnicki, Konflikt dóbr i kolizji norm, „Ruch Prawniczy, Ekonomiczny i Socjologiczny” 1989, s. 14.

7 Oceniając przesłankę ważnego interesu podatnika, należało mieć na względzie również interes publiczny, na co zwraca uwagę wyrok NSA z dnia 21 marca 2001 r., I SA/Ka 577/00, LEX nr 47500.

8 Zob. wyrok WSA w Szczecinie z dnia 9 grudnia 2009 r., I SA/Sz 667/09, LEX nr 549964.

9 Zob. wyrok NSA z dnia 9 maja 2003 r., III SA 2679/01, LEX nr 146084.

10 Zgodnie $\mathrm{z}$ art. 217 Konstytucji RP zasady przyznawania ulg i umorzeń winny być uregulowane w ustawie. Konstytucja, na co wielokrotnie zwracał uwagę Trybunał Konstytucyjny, daje ustawodawcy znaczną swobodę w kształtowaniu tych zasad, nie wskazując przesłanek ich udzielania. O kształcie przyjętych rozwiązań decydują bowiem w tym przypadku nie tyle przesłanki o charakterze prawnym, co przesłanki ekonomiczne i społeczne. Por. orzeczenie TK z dnia 29 maja 1996 r., K 22/95, OTK 1996, nr 3, poz. 21. 
6.

Należy również zwrócić uwagę, że stosowanie klauzul generalnych może stanowić nie tylko zagrożenie dla bezpieczeństwa prawnego gwarantującego pewność prawa, ale także zastrzeżenia natury konstytucyjnej. Stosowanie klauzul generalnych może naruszać konstytucyjną zasadę sprawiedliwości i równości opodatkowania ${ }^{11}$. Brak równości w opodatkowaniu może być jednak wynikiem nie tylko wadliwego stosowania prawa, ale i stanowienia prawa podatkowego $\mathrm{z}$ uwzględnieniem klauzul generalnych.

Źródłem tego ostatniego zjawiska może być zastosowanie przepisu art. 22 $\S 1$ pkt 1 Ordynacji podatkowej, który zawiera normę kompetencyjną do wydawania rozporządzeń. W przepisie tym zawarto szczegółowe upoważnienie dla Ministra Finansów do wydawania rozporządzeń w celu wykonania ustawy. Rozporządzenia wydane na podstawie art. $22 \S 1$ pkt 1 Ordynacji podatkowej wymagają więc każdorazowej oceny skutków rozstrzygnięć prawnych, jakie mogą powstać w wyniku zastosowania tego przepisu. Klauzula generalna użyta we wskazanej normie kompetencyjnej może mieć natomiast odrębną treść znaczeniową w zależności od rodzaju podatku, okresu, w którym następuje zaniechanie i grupy podatników, których ono dotyczy. Ponadto w rozporządzeniu mogą zostać zawarte warunki, które w sposób nieuzasadniony będą preferować określone grupy podatników, pomijając inne.

Jak powiedziano, istotną rolę $\mathrm{w}$ stosowaniu klauzul generalnych mają zobiektywizowane kryteria oceny przesłanki ważnego interesu podatnika oraz interesu publicznego. Treść klauzul generalnych jest zróżnicowana pod względem użytych w nich pojęć, zwrotów i wyrażeń. W przyjętych przez ustawodawcę kryteriach oceny, jakie nasuwają klauzule generalne, przesłanka interesu podatnika została opatrzona w przepisach art. 22 , art. $48 \S 1$ i 2 , art. 67 a $\S 1$ pkt 1, 2 i 3 oraz art. 253 i 253a Ordynacji podatkowej przymiotnikiem „ważny”. Nie może to być zatem jakikolwiek interes, rozumiany jako przysporzenie finansowe dla podatnika lub określonej grupy podatników, którą mogą odnieść w każdych okolicznościach sprawy. Jej uzyskanie musi być poprzedzone uznaniem przez organ podatkowy, że sprawa wymagająca załatwienia ma kwalifikowany charakter.

W treści norm prawnych zawierających klauzule generalne, wskazujących na ważny interes podatnika, należy $z$ tego powodu dostrzegać, o czym powiedziano wyżej, nadzwyczajne względy, a więc takie, które mogłyby zachwiać podstawami

11 Zob. wyrok WSA z dnia 26 marca 2015 r., I SA/Sz 1226/14, CBOSA. 
egzystencji podatnika ${ }^{12}$. W takiej interpretacji przepisów zawartych w Ordynacji podatkowej przejawia się pozafiskalny cel klauzul generalnych. Aby uznać, że warunki ważnego interesu podatnika zostały spełnione, musi zostać przeprowadzone przez organ podatkowy postępowanie dowodowe.

8.

Należy podkreślić, że wprowadzenie pojęcia ważnego interesu podatnika oraz interesu publicznego do klauzul generalnych tworzy warunki dla stosowania przez organ podatkowy instytucji tzw. uznania administracyjnego. W toku postępowania podatkowego, uwzględniającego tzw. uznanie administracyjne, trzeba zatem dokonać każdorazowo oceny zaistniałych okoliczności oraz ustalić, czy w rozpatrywanej sprawie występuje oraz na czym polega ważny interes podatnika lub interes publiczny ${ }^{13}$.

Posłużenie się przez ustawodawcę pojęciami nieokreślonymi i odesłaniem do własnego rozeznania wymaga od organu podatkowego wszechstronnego wyjaśnienia okoliczności faktycznych po to, aby na tej podstawie stwierdzić, czy dana sytuacja faktyczna mieści się w zakresie przesłanki ważnego interesu podatnika lub interesu publicznego czy też nie ${ }^{14}$. $Z$ tego powodu organ podatkowy jest obowiązany przy wydawaniu rozstrzygnięcia w ramach tzw. uznania administracyjnego zbadać stan faktyczny w najdokładniejszy sposób i - co oczywiste - utrwalić go w aktach sprawy ${ }^{15}$. Do tak ustalonego stanu faktycznego należy odnieść zobiektywizowane kryteria oceny przesłanki ważnego interesu podatnika oraz interesu publicznego.

Nie oznacza to jednak, że jeśli organ podatkowy stwierdzi, iż występują przesłanki ważnego interesu podatnika lub interesu publicznego w konkretnym stanie faktycznym, przesądza to w sposób mechaniczny o obowiązku np. odroczenia terminu płatności podatku przez organ podatkowy, odroczenia lub rozłożenia na

12 Przepis art. $22 \S 2$ pkt 1 Ordynacji podatkowej stanowi, że organ podatkowy może zwolnić płatnika z obowiązku pobrania podatku, jeżeli pobranie podatku zagraża ważnym interesom podatnika, a w szczególności jego egzystencji. Na ten temat zob. bliżej: B. Gruszczyński, Komentarz do art. 22, [w:] S. Babiarz, B. Dauter, B. Gruszczyński, R. Hauser, A. Kabat, M. Niezgódka-Medek, Ordynacja podatkowa. Komentarz, Warszawa 2013, s. 219-222; A. Gomułowicz, A. Skoczylas, Zwolnienie platnika z obowiazku pobrania podatku (art. 22 \& o.p.), ograniczanie poboru zaliczek na podatek (art. 22 \& 2 a o.p.), [w:] A. Choduń, A. Gomułowicz, A. Skoczylas, op. cit., s. 45 i n. Por. także: wyrok NSA z dnia 26 lipca 2011 r., sygn. akt II FSK 425/10; wyrok NSA z dnia 19 sierpnia 2010 r., II FSK 619/09, CBOSA.

13 Zob. wyrok NSA z dnia 18 maja 2005 r., II FSK 2211/04, CBOSA.

14 Odpowiedź podsekretarza stanu w Ministerstwie Finansów na interpelację nr 17659 w sprawie podejścia organów skarbowych do próśb o rozłożenie na raty orzeczonych, zaległych należności skarbowych.

15 Zob. wyrok NSA z dnia 7 lutego 2001 r., I SA/Gd 1507/00, LEX nr 46473. 
raty zapłaty zaległości podatkowej albo jej umorzenia ${ }^{16}$. Przesłanki faktyczne muszą zostać skonfrontowane z wartościami określonymi w klauzuli generalnej. Powinny one pozostawać w zgodzie z założeniami ogólnie przyjętego w państwie systemu wartości, uwzględniając konstytucyjne wolności gospodarcze, socjalne, kulturalne i inne, chroniąc nie tylko sferę indywidualną, ale również wypełniając funkcje ogólne.

9.

Reasumując, prawodawstwo podatkowe powinno zawierać regulacje zapewniające względną trwałość przepisów jako czynnika warunkującego bezpieczeństwo prawne i zaufanie do organów stanowiących i stosujących prawo. Środkiem techniki prawodawczej pozwalającej na pogodzenie sprzeczności między trwałością i elastycznością prawa podatkowego jest posługiwanie się klauzulami generalnymi. Odesłanie w przepisach prawnych do pozaprawnych ocen zdarzeń i zjawisk dokonywanych przez organy podatkowe nie powoduje konieczności zmiany prawa. Dla stosowania klauzul generalnych niezbędna jest jednak obserwacja kierunków zmian w ocenach założeń ogólnych przyjętego systemu wartości oraz ich powodów i zależności od społecznego otoczenia, w którym funkcjonują. To z kolei jest warunkiem zapewniającym elastyczne stanowienie i stosowanie prawa podatkowego.

\section{BIBLIOGRAFIA}

Borszowski P., Elastyczność a zwrot szacunkowy ,, ważny interes podatnika” w konstrukcji umorzenia zaległości podatkowych, [w:] Instytucje prawnofinansowe w warunkach kryzysu gospodarczego, red. W. Miemiec, K. Sawicka, Warszawa 2014.

Choduń A., Klauzule generalne i zwroty niedookreślone - wybrane zagadnienia teoretyczne, [w:] A. Chodun, A. Gomułowicz, A. Skoczylas, Klauzule generalne i zwroty niedookreślone w prawie podatkowym i administracyjnym. Wybrane zagadnienia teoretyczne i orzecznicze, Warszawa 2013.

Gizbert-Studnicki T., Konflikt dóbr i kolizji norm, „Ruch Prawniczy, Ekonomiczny i Socjologiczny” 1989.

Gomułowicz A., Skoczylas A., Zwolnienie płatnika z obowiązku pobrania podatku (art. 22 § o.p.), ograniczanie poboru zaliczek na podatek (art. 22 \& 2 o o.p.), [w:] A. Choduń, A. Gomułowicz, A. Skoczylas, Klauzule generalne i zwroty niedookreślone $w$ prawie podatkowym $i$ administracyjnym. Wybrane zagadnienia teoretyczne i orzecznicze, Warszawa 2013.

Gruszczyński B., Komentarz do art. 22, [w:] S. Babiarz, B. Dauter, B. Gruszczyński, R. Hauser,

A. Kabat, M. Niezgódka-Medek, Ordynacja podatkowa. Komentarz, Warszawa 2013.

Hanusz A., Podstawa faktyczna rozstrzygnięcia podatkowego, Kraków 2004.

16 Zob. na ten temat: A. Hanusz, Podstawa faktyczna rozstrzygnięcia podatkowego, Kraków 2004, s. 80-81. 
Leszczyński L., Interpretacyjna rola kryteriów otwartych i innych decyzji stosowania prawa, [w:] System Prawa Administracyjnego, t. 4: Wykładnia w prawie administracyjnym, red. L. Leszczyński, B. Wojciechowski, M. Zirk-Sadowski, Warszawa 2015.

Leszczyński L., Stosowanie generalnych klauzul odsyłających, Kraków 2001.

Leszczyński L., Tworzenie generalnych klauzul odsyłających, Lublin 2000.

Orzeczenie TK z dnia 29 maja 1996 r., K 22/95, OTK 1996, nr 3, poz. 21.

Wyrok NSA z dnia 7 lutego 2001 r., I SA/Gd 1507/00, LEX nr 46473.

Wyrok NSA z dnia 21 marca 2001 r., I SA/Ka 577/00, LEX nr 47500.

Wyrok NSA z dnia 18 maja 2005 r., II FSK 2211/04, CBOSA.

Wyrok NSA z dnia 19 sierpnia 2010 r., II FSK 619/09, CBOSA.

Wyrok NSA z dnia 26 lipca 2011 r., sygn. akt II FSK 425/10.

Wyrok NSA z dnia 9 maja 2003 r., III SA 2679/01, LEX nr 146084.

Wyrok WSA w Szczecinie z dnia 9 grudnia 2009 r., I SA/Sz 667/09, LEX nr 549964.

Wyrok WSA z dnia 26 marca 2015 r., I SA/Sz 1226/14, CBOSA.

Ziembiński Z., Teoria prawa, Warszawa - Poznań 1973.

\section{SUMMARY}

General clauses cause "flexibility of legal act", and consequently "application of legal provisions". Without general clauses it is impossible to extend legal regulations to all events, giving effects, occuring in abandonment of tax collection, exemption from obligation of tax collection or tax deductions, advantages like deferment of the payment of that tax or remitting the whole or a part of tax arrears. Phrases like taxpayer's important interest and public interest, beeing used in the regulations of the Tax Ordinance Act, have not regular range of content. During dealing with complaints, the tax authorities are obliged to fill these phrases with an appropariete content, in its sole discretion. This is done within the framework of so-called administrative discretion. The tax authorities have also a margin of discretion, both with regard to the interpretation of expressions and phrases being the content of general clauses and in evaluation of factual situation of the case. Simultaneusly, general clauses contained in Tax Ordinance Act, enable to choose legal consequences and resolve conflict of goods specified within. Essential directives of choice are contained in generally accepted value system. But these values do not have a direct impact at the choice of determined settlement.

Keywords: general clauses; Tax Ordinance Act; taxpayer's important interest; public interest

\section{STRESZCZENIE}

Użyte w przepisach Ordynacji podatkowej takie zwroty, jak ,ważny interes podatnika” i ,interes publiczny" nie mają stałego zakresu treści. Organy podatkowe podczas rozpatrywania poszczególnych spraw obowiązane są zatem wypełnić te pojęcia właściwą zawartością według własnego rozeznania. $\mathrm{Z}$ tego powodu doniosłą rolę w stosowaniu klauzul generalnych mają kryteria oceny ważnego interesu podatnika oraz interesu publicznego, które muszą mieć charakter zobiektywizowany. Klauzule generalne ujęte w Ordynacji podatkowej pozwalają na dokonywanie wyboru określonych w niej konsekwencji prawnych i rozstrzygania konfliktu dóbr. Jest to dokonywane w ramach tzw. uznania administracyjnego. Dyrektywy wyboru tkwią w założeniach ogólnych oficjalnie przyjętego systemu wartości. Ustaleniu właściwego znaczenia norm zawierających tego rodzaju środki techniki prawodawczej musi towarzyszyć przekonanie, że tworzenie prawa nie odbywa się w oderwaniu od wpływów aksjologicznych. Uwzględniają one konstytucyjne wolności gospodarcze, socjalne, kulturalne i inne. Klauzule generalne wykorzystywane w prawie podatkowym, przy 
zachowaniu stabilności przepisów prawnych, powodują jednocześnie uelastycznienie tekstu aktu prawnego, a co za tym idzie - stosowanie przepisów prawnych. Użycie przez prawodawcę klauzul generalnych nie jest równoznaczne z przyznaniem interpretatorowi absolutnej i pozostającej poza wszelką kontrolą dowolności wykładni przepisów prawnych. Musi on posługiwać się zobiektywizowanymi kryteriami ocen pozaprawnych zdarzeń i zjawisk prawnie istotnych znajdujących uzasadnienie aksjologiczne.

Słowa kluczowe: klauzule generalne; Ordynacja podatkowa; ważny interes podatnika; interes publiczny 